\title{
Sistem Merit pada Sektor Pemerintahan : Proses Pengisian dan Penempatan Jabatan Pelaksana di Badan Kepegawaian Daerah Jawa Tengah
}

\section{Merit System In Public Sector: Staff Placement Process In Regional Human Resource Office Of Central Java Province Government Ahmad Faiz, Retno Sunu Astuti \& Teuku Afrizal*}

\author{
Magister Administrasi Publik, Fakultas Ilmu Sosial dan Ilmu Politik \\ Universitas Diponegoro, Indonesia
}

Diterima: 14 Juni 2020; Disetujui: 12 Juli 2020; Dipublish: 18 Juli 2020

\begin{abstract}
Abstrak
Perubahan kebijakan birokrasi tentang Aparatur Sipil Negara menuntut perubahan manajemen SDM Aparatur berbasis merit system khususnya dalam pengisian Jabatan Pelaksana di birokrasi pemerintahan. Penelitian ini bertujuan untuk mendeskripsikan merit system dalam proses pengisian dan penempatan Jabatan Pelaksana di Badan Kepegawaian Daerah Provinsi Jawa Tengah dan faktor-faktor yang mempengaruhi proses tersebut. Metode penelitian yang digunakan kualitatif dengan pengumpulan data primer melalui teknik wawancara mendalam dan observasi, sedangkan data sekunder dikumpulkan melalui arsip dan dokumentasi. Hasil penelitian menunjukkan bahwa proses pengisian dan penempatan SDM Jabatan Pelaksana di Badan Kepegawaian Daerah Provinsi Jawa Tengah yang berasal dari seleksi CPNS tahun 2014 dan tahun 2018 sudah sesuai dengan prinsip merit system, meskipun belum sepenuhnya diterapkan secara keseluruhan. Masih terdapat penempatan PNS yang belum sesuai dengan kebutuhan jabatan yaitu kualifikasi dan pangkat yang dipersyaratkan dalam menduduki jabatan tersebut (job spesification). Perlu diketahui juga bahwa dalam penilaian kinerja melalui Sasaran Kerja Pegawai (SKP) bulanan, kedisiplinan dan kehadiran fingerprint yang berpengaruh pada Tambahan Penghasilan Pegawai (TPP). Teridentifikasi juga beberapa faktor yang mempengaruhi proses pengisian dan penempatan pejabat pelaksana, yaitu komitmen pimpinan, sumberdaya manusia dan regulasi.

Kata kunci: Merit System, Kompetensi, Penempatan Pegawai, Jabatan Pelaksana
\end{abstract}

\begin{abstract}
Changes in bureaucratic policy on the State Civil Apparatus require changes in the management of Human Resources Apparatus based on merit systems, especially in filling the Executive Position in the government bureaucracy. The purpose of this research is to describe the merit system in the process of filling out and placing the Executive Position in the Central Java Regional Civil Service Agency and the factors that influence the process. The research method used is qualitative by collecting primary data through in-depth interviews and observation techniques, while secondary data is collected through archives and documentation. The results showed that the process of filling and placing HR of Implementing Positions in the Central Java Regional Personnel Agency originating from CPNS selection in 2014 and 2018 was in accordance with the principle of merit system, although it was not fully implemented as a whole. There are still civil servant placements that are not in accordance with the needs of the position, namely the qualifications and rank required in occupying the position (job specifications). It should also be noted that in the performance appraisal through the monthly Employee Work Target (SKP), discipline and attendance of a fingerprint affect the Additional Employee Income (TPP). Also identified several factors that influence the process of filling and placing executive officers, namely the commitment of leaders, human resources and regulations.

Keywords: Merit System, Competence, Employee Placement, Implementing Positions
\end{abstract}

How to Cite: Faiz, A. Astuti, R.S \& Afrizal, T. (2020). Sistem Merit pada Sektor Pemerintahan: Proses Pengisian dan Penempatan Jabatan Pelaksana di Badan Kepegawaian Daerah Jawa Tengah. PERSPEKTIF, 9(2): 406-416

*Corresponding author:

E-mail: teukurian@lecturer.undip.ac.id ISSN 2085-0328 (Print) ISSN 2684-9305(Online) 


\section{PENDAHULUAN}

Sistem merit merupakan suatu proses rekruitmen, penunjukan dan promosi pegawai berdasarkan kemampuan untuk melaksanakan pekerjaan. Pendekatan ini telah menjadi masintream dalam manajemen kepegawaian pemerintah di Indonesia. Undang-Undang Nomor 5 Tahun 2014 tentang Aparatur Sipil Negara (ASN) telah menerapkan prinsip-prinsip sistem merit dalam proses rekruitmen, pengangkatan pegawai, penempatan, mutasi, promosi, penggajian, penghargaan dan pengembangan karier hingga pemberhentian. Undang-Undang tersebut merupakan payung hukum dari seluruh aturan-aturan menejemen kepegawaian yang lebih teknis, sekaligus merupakan tonggak penting reformasi birokrasi di Indonesia.

Perubahan regulasi dengan merit system dalam Undang-Undang Aparatur Sipil Negara (ASN) dalam (Administrasi, 2020) meletakan 6 (enam) perubahan mendasar dalam sistem manajemen SDM yang belum secara tegas terdapat dalam dua kebijakan sebelumnya yaitu undang Nomor 43 Tahun 1999 tentang Perubahan atas Undang-Undang No. 8 Tahun 1974 tentang Pokok-pokok Kepegawaian, yakni:

1. perubahan dari pendekatan pegawai administratif dalam pencatatan administratif kepegawaian kepada Human Capital Management, dimana sumber daya dianggap sebagai aset negara yang harus dikelola, dihargai dan dikembangkan dengan baik;

2. perubahan pada sistem karir PNS, yakni dari pendekatan close-career system yang sebelumnya mengutamakan senioritas dan kepangkatan kepada open-career system yang mengedepankan kompetisi dan kinerja dalam pengisian jabatan;

3. membentuk lembaga Komisi Aparatur Sipil Negara (KASN) yang secara khusus bertugas menegakan dan mengawal implementasi sistem merit di Kementerian/Lembaga Negara dan Pemerintahan Daerah;

4. menghadirkan Pegawai Pemerintah dengan Perjanjian Kerja (PPPK) dalam sistem kerja yang berkompetensi;

5. penerapan reward dan punishment berbasis kinerja pegawai yang dihasilkan yang lebih tegas;
6. meningkatkan perlindungan ASN dari intervensi politik.

Undang-undang tersebut membagi nomenklatur jabatan menjadi 3 jenis, Jabatan Pimpinan Tinggi (JPT), Jabatan Administratif (JA), dan Jabatan Fungsional (JF). Hal ini berbeda dengan nomenklatur jabatan sebelumya, yaitu jabatan struktural dan

fungsional sesuai dengan Undang-Undang Nomor 43 Tahun 1999 tentang Perubahan atas Undang-Undang No. 8 Tahun 1974 tentang Pokok-pokok Kepegawaian. Jabatan struktural terdiri dari 5 tingkat jabatan, yaitu yang terbawah Eselon V, sampai dengan yang paling atas, Eselon I. JPT dan JA memiliki kesetaraan dengan jabatan eselon tersebut, namun dengan karakteristik yang berbeda. Jabatan struktural dan fungsional dalam nomenklatur lama cenderung berdiri sendiri dan memiliki track karir masing-masing, meski pejabat struktural bisa inpassing ke jabatan fungsional, dan sebaliknya pejabat fungsional bisa ditugaskan dalam suatu jabatan struktural. Dalam nomenklatur jabatan ASN, hal sejenis berlaku bagi JA dan JF. Sementara itu, JPT menjadi semacam kelanjutan karir baik dari JA maupun JF, sehingga jika digambarkan hubunganya tampak seperti Tabel 1.

Tabel 1. Kesetaraan JPT dan JA dengan Sistem Eselonisasi

\begin{tabular}{lll}
\hline $\begin{array}{l}\text { Jabatan Pimpinan } \\
\text { Tinggi (JPT) }\end{array}$ & $\begin{array}{l}\text { Jabatan } \\
\text { Administratif }\end{array}$ & $\begin{array}{l}\text { Jabatan } \\
\text { Eselon }\end{array}$ \\
\hline $\begin{array}{l}\text { JPT Utama dan } \\
\text { Madya }\end{array}$ & - & Eselon I \\
\hline JPT Pratama & - & \\
\hline- & Administrator & Eselon II \\
\hline- & Pengawas & Eselon IV \\
\hline- & Pelaksana & Eselon V \\
\hline
\end{tabular}

Sumber : data sekunder yang diolah

Lebih lanjut, Undang-undang ASN tersebut kemudian diturunkan kedalam beberapa aturan operasional. Diantaranya yang paling esensial adalah Peraturan Pemerintah Nomor 11 Tahun 2017 tentang Manajemen PNS. Aturan tersebut secara komprehensif mencakup pedoman need assessment, provisi, penentuan pangkat, penempatan jabatan, pengembangan dan pola karir, promosi, mutasi, penilaian kinerja, penghargaan, disiplin, pemberhentian, dan aspek lain terkait sistem merit. Menurut UU 5 Tahun 2014, ASN terdiri 
dari PNS dan PPPK. Jika manajemen PNS diatur dalam PP 11Tahun 2017, manajemen PPPK diatur tersendiri dalam PP 49 Tahun 2018, dimana disebutkan bahwa jenis jabatan yang pengadaannya melalui PPPK adalah jabatan pimpinan tinggi dan fungsional. Provisi pegawai melalui mekanisme PPPK dengan demikian bisa dimaknai dalam konteks untuk mengisi posisi jabatan yang belum bisa diisi oleh ASN.

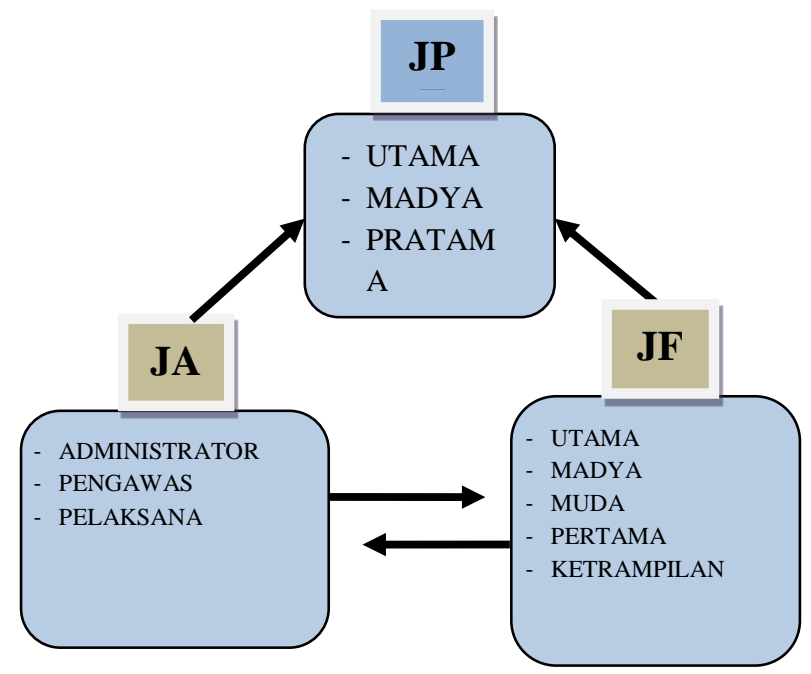

Gambar 1. Hubungan Jabatan ASN

Sumber : data sekunder yang diolah

Penerjemahan aturan turunan UU ASN tersebut, terutama PP 11 Tahun 2017, telah banyak dilakukan oleh kementerian terkait. KemenPAN, sebagai leading sector reformasi birokrasi di Indonesia misalkan,menerbitkan PermenPAN 13/2019 tentang penetapan dan pembinaan jabatan fungsional PNS. Aturanaturan mengenai JF ini juga telah mengalami evolusi sedemikian rupa, dan semakin sinkron dengan isi UU ASN. Terlepas dari perkembangan reformasi birokrasi terkini di Indonesia, posisi JF sendiri relatif lebih terlembaga. Dari sekian puluh jenis JF, masingmasing memiliki tatanan sendiri dimana pengaturan kenaikan pangkat dan jabatan proprosional dengan kerja keras atau karya yang dihasilkan yang direpresentasikan dengan perolehan angka kredit. Dalam hal ini, jenjang karir JF berlaku otomatis tanpa memerlukan mekanisme tersendiri seperti halnya sistem promosi pada JPT dan JA.

Dengan demikian, keseluruhan jenis jabatan yang disebutkan dalam UU ASN telah memiliki instrument sistem merit yang cukup komprehensif untuk diterapkan semua instansi pemerintah, baik di tingkat pusat maupun daerah. Namun, prinsip-prinsip merit dalam manajemen kepegawaian belum secara penuh bisa diterapkan di lapangan. Beberapa studi mengkonfirmasi hal tersebut. Penelitian yang dilakukan oleh (Ali, n.d.), misalkan, menemukan bahwa promosi jabatan, meski sudah dilakukan secara selektif dan dengan kompetisi terbuka, masih dipengaruhi hubungan kolegial atau kekerabatan. Penelitian lain yang dilakukan oleh (Utha \& Dinamita, 2017) juga menemukan bahwa Penempatan PNS dalam jabatan struktural yang dipilih belum berdasakan merit system tetapi masih dipengaruhi kepentingan partai politik, kedekatan pada Bupati/Kepala Daerah, berdasarkan nepotisme, persahabatan dan kekeluargaan. Temuan yang hampir sama didapatkan oleh (Administrasi, 2020), dimanapelaksanaan pengisian Posisi Jabatan Administratif (khususnya Administrator dan Pengawas) belum sepenuhnya didasarkan pada prinsip-prinsip sistem merit. Masih terdapat perbedaan prosedur antara Unit Kerja dalam menentukan kandidat dan tidak adanya standar kompetensi dan pelaksanaan rotasi kerja tidak didasarkan pada pola karir.

Penelitian terkait sistem merit pada sektor publik yang telah banyak dilakukan umunya fokus disekitar isu promosi atau pengangkatan kedalam JPT dan JA (khususnya adminitrator/ eselon III, dan pengawas/ eselon IV). Pengisian jabatan pimpinan tinggi (pratama) menjadi fokus beberapa studi, misalkan (Wijaya et al., 2019), yang meneliti regulasi penempatan pejabat tingkat tinggi dan implementasinya di pemerintah kota Palembang. Penelitian sejenis yang lain dilakukan oleh (Mamuju, 2019) dengan studi lapanganya di Kabupaten Mamuju Tengah. Sementara itu, studi yang dilakukan (Utha \& Dinamita, 2017), (Siregar, Irwan, Indra, 2017), (Hardiyanto, 2011), (Pulungan, 2011), (Administrasi, 2020) fokus pada faktor-faktor yang mempengaruhi penempatan pejabat administrasi (administrator dan pengawas). Seperti yang diuraikan sebelumnya, para peneliti ini memiliki kesamaan pandangan bahwa realitas dilapangan belum sepenuhnya berjalan sesuai ekspektasi yang dicita-citakan reformasi birokrasi di Indonesia.

Beberapa penelitian yang diulas di atas, belum satupun yang memiliki fokus pada segmen jabatan pelaksana. Sebagai bagian dari 
JA, pelaksana memiliki peran yang tidak kalah penting dalam sistem merit. Jabatan ini yang justru menjadi garda terdepan untuk melaksanakan layanan publik, sehingga kompetensinya menjadi faktor yang krusial dalam sistem merit. PermenPAN 41 Tahun 2018 mengatur secara tersendiri tentang nomenklatur jabatan pelaksana. Pengelompokan jabatan tersebut didasari pada kesamaan karakteristik, mekanisme dan pola kerja. Setiap jenis jabatan memiliki tugas jabatan, kualifikasi pendidikan minimal yang dipersyaratkan.

Jabatan pelaksana disandang seorang ASN mulai sejak awal perekrutan sampai kemudian dipromosikan kedalam tingkat jabatan yang lebih tinggi, yaitu pengawas.Studi terkait merit system dalam aspek rekruitmen (CPNS) misalkan dilakukan oleh (Setyowati, 2016). Temuanya menunjukan bahwa prinsipprinsip merit belum diterapkan dalam proses tersebut. Hal tersebut berlaku bahkan mulai dari saat pengajuan formasi yang belum merefleksikan kebutuhan birokrasi, adanya indikasi korupsi-kolusi-nepotisme dalam proses perekrutan, dan penentuan seleksi yang tidak berdasarkan passing-grade. Sementara itu, aspek penempatan pejabat pelaksana belum banyak menjadi fokus khusus. Meski demikian, beberapa studi memiliki irisan isu, misalkan dilakukan oleh (Putri et al., 2017). Penelitianya fokus pada penempatan pegawai secara umum. Dengan mempertimbangkan job specification dan job description sebagai faktor penting yang mendasarinya, penempatan pegawai belum mempertimbangkan kemampuan masing-masing secara tepat.Tidak ada penekanan pada isu jabatan pelaksana didalamnya. Demikian juga studi yang dilakukan oleh (Series \& Science, 2017), penelitian tersebut fokus pada penempatan pegawai secara umum. Penelitian yang dilakukan di Kantor Kecamatan Labuhanbatu tersebut melibatkan pimpinan dan staf dibeberapa seksi. Hal ini berarti penelitian tersebut mencakup semua pegawai, baik administrator, pengawas dan pelaksana. Berbeda dengan penelitian sebelumnya, kesimpulan yang diambil adalah terdapat pengaruh positif dari variable latar belakang pendidikan, pengetahuan, keterampilan, pengalaman kerja dan etika terhadap penempatan dan kinerja pegawai.
Dengan semua instrument regulasi yang menopang sistem merit pada sektor publik di Indonesia sebagaimana diuraikan diatas, apakah implementasi dilapangan telah secara tuntas dilaksanakan? Temuan dari beberapa studi menunjukan bahwa masih banyak pekerjaan rumah yang harus diselesaikan, baik dalam konteks penempatan jabatan pimpinan tinggi maupun jabatan administratif. Namun, jenis jabatan terakhir ini masih menyisakan pertanyaan, terutama terkait dengan jabatan lini pertamanya, yaitu pelaksana.Kaitan dengan hal tersebut, transformasi kedalam sitem merit telah ditopang oleh terbitnya PermenPAN Nomor 41 Tahun 2018. Setelah 2 tahun berjalan, apakah instrument tersebut telah terimplementasikan secara baik dilapangan? Sependek pengetahuan penulis, belum ada studi yang secara spesifik dan konklusif mengafirmasinya. Dengan mengambil kasus di BKD Jawa Tengah, penelitian ini didedikasikan untuk menjelaskan gap tersebut.

\section{METODE PENELITIAN}

Metode penelitian yang digunakan dengan tipe penelitian deskriptif kualitatif dan lokus penelitan di BKD Provinsi Jawa Tengah. Data yang digunakan dalam penelitian ini adalah data primer dan data sekunder.

Sumber data yang digunakan dalam bentuk primer data yang diperoleh dari wawancara mendalam dan observasi. Adapun informan penelitian ditentukan secara purposive melibatkan Pengampu Kepegawaian di Badan kepegawaian Daerah Provinsi Jawa Tengah yaitu Pejabat Pengawas dan Administrator membahas tentang pemetaan dan penempatan pegawai, Pejabat Pengawas Kementerian PAN dan RB yang menangani penempatan membahas tentang regulasi serta wawancara dengan Jabatan Pelaksana yang menangani kegiatan penempatan membahas tentang pelaksanaannya di BKD Provinsi Jawa Tengah. Sedangkan data sekunder dalam bentuk arsip dan dokumentasi. Adapun dokumen berupa data kepegawaian PNS http://simpeg.bkd.jatengprov.go.id/ dan digali kesesuaian kualifikasi PNS tersebut, kemudian data arsip CPNS Tahun 2014 dan Tahun 2018 digali formasi CPNS dan penempatan CPNS dan PNS pada instansi, dan dokumen lainnya berkaitan penempatan pegawai seperti dokumen rakor dan desk penempatan serta 
contoh SK penempatan PNS dalam jabatan pelaksana.

Peneliti dalam melakukan pengumpulan data menggunakan teknik triangulasi dengan menggabungkan beberapa teknik, yakni wawancaraa mendalam, observasi dan dokumentasi. Wawancara merupakan metode pengumpulan data dengan cara mengunjungi langsung seseorang yang memiliki kapasitas dalam menjawab pertanyaan. Wawancara dilakukan secara mendalam dengan menemui langsung pejabat yang terkait. Pengumpulan data dengan mengobservasi tentang kejadian pelaksanaan penempatan PNS dan faktor yang mempengaruhi dalam konteks merit sistem khususnya jabatan pelaksana di BKD Provinsi Jawa Tengah. Teknik dokumenter/ dokumentasi adalah proses mengumpulkan kebutuhan data dengan cara meneliti dokumen yang berkaitan dengan fenomena yang diteliti dilapangan.peneliti mengumpulkan data dengan cara meneliti arsip dan dokumendokumen yang berkaitan dengan obyek yang diteliti.

Peneliti memilih model Miles, Huberman dan Saldana (2014), dalam teknik mengalisis data. Terdapat tiga aktivitas dalam analisa data, yaitu : kondensasi data (data condensation), penyajian data (data display dan drawing) dan penarikan kesimpulan (verifying conclusions).

\section{HASIL DAN PEMBAHASAN \\ Penyusunan Kebutuhan dan Pengadaan Pegawai}

Manajemen SDM PNS dimulai dengan tahap penyusunan formasi dan penetapan kebutuhan, pengadaan pegawai, penentuan pangkat dan penempatan jabatan. Penyusunan formasi dan kebutuhan pegawai melalui Analisis Jabatan dan Analisis Beban Kerja. Analisis jabatan dan analisis beban kerja berisi uraian penugasan dan uraian pekerjaan jabatan dengan tahapan membentuk tim pelaksana analisis jabatan dan Analisis Beban Kerja. Tahapan selanjutnya dilakukan persiapan, pengumpulan data jabatan, pengolahan data jabatan, verifikasi jabatan, uraian jabatan, spesifikasi jabatan, validasi kebutuhan, jumlah pegawai, jumlah kurang atau kelebihan pegawai. Kemudian penetapan peta jabatan oleh Pejabat Pembina Kepegawaian (PPK) dalam hal ini Kepala Daerah. Sedangkan tahapan terakhir, adalah data peta jabatan diinput pada aplikasi $e$ - formasi KemenPAN dan RB. Hal ini merupakan amanah dari UU No. 5 Tahun 2014 tentang ASN bahwa setiap instansi pemerintah wajib menyusun kebutuhan jumlah serta jenis jabatan Pegawai Negeri Sipil (PNS) berdasarkan analisis jabatan dan analisis beban kerja. Peraturan yang mendasari pelaksanaan tersebut adalah Peraturan Menteri Pendayagunaan Aparatur Negara Dan Reformasi Birokrasi Republik Indonesia Nomor 1 Tahun 2020 Tentang Pedoman Analisis Jabatan dan Analisis Beban Kerja. Analisis jabatan merupakan proses pengumpulan informasi tentang jabatan tertentu dan proses sistematis menentukan ketrampilan, tugas, dan pengetahuan yang diperlukan untuk melakukan pekerjaan tertentu dalam organisasi.

Jumlah jabatan dan uraian jabatan pada tahun 2019 di BKD Provinsi Jawa Tengah dan sudah ditetapkan dalam peta jabatan sesuai dasar Peraturan Gubernur Nomor 57 Tahun 2018 tentang Uraian Jabatan PNS di Lingkungan Pemerintah Provinsi Jawa Tengah sebanyak 60 nomenklatur jabatan meliputi 1 nomenklatur jabatan Pimpinan Tinggi Pratama, 6 nomenklatur Jabatan Administrator, 16 nomenklatur Jabatan Pengawas, 7 nomklatur jabatan Fungsional dan 30 nomenklatur jabatan pelaksana. Selain itu, kondisi yang termuat di peta jabatan masih terjadi kekosongan atau kurang pegawai dalam pengisian jabatan terutama jabatan fungsional dan pelaksana. Hal tersebut menjadi acuan dasar juga dalam pengadaan pegawai. (Sumber :Data Kepegawaian BKD Provinsi Jawa Tengah, 2019).

Pengadaan pegawai di Pemerintah Provinsi Jawa Tengah mulai pada tahun 2014 dan tahun 2018 dengan menggunakan Computer Assisted Test (CAT). Sedangkan pengadaan CPNS pada tahun 2018 sebanyak 1926 formasi, dengan penempatan CPNS di BKD Provinsi Jawa Tengah sebanyak 6 formasi meliputi 3 jabatan fungsional arsiparis terampil, 2 jabatan fungsional auditor kepegawaian dan 1 jabatan pelaksana penata laporan keuangan. Adapun pelaksanaan tes dengan menggunakan SKD dan SKB sistem Computer Asisted Test (CAT) dengan passing grade sesuai Peraturan MenPAN dan Reformasi Birokrasi Nomor 37 Tahun 2018 tentang Nilai Ambang Batas Seleksi Kompetensi Dasar Pengadaan Calon Pegawai 
Negeri Sipil Tahun 2018 antaralain: Tes Karakteristik Pribadi (TKP) nilai 143, Tes Intelegensia Umum (TIU) dengan nilai 80; dan Tes Wawasan Kebangsaan (TWK) nilai 75. Kemudian peserta yang lulus kompetensi dasar dapat mengikuti kompetensi bidang. Hasil akumulasi kompetensi dasar dan kompetensi bidang menentukan kelulusan CPNS.

Setelah kelulusan CPNS tahun 2014 dan 2018 ditempatkan sesuai instansi formasi yang dilamar. Kemudian CPNS telah menjalani masa percobaan dan lulus dapat diangkat menjadi PNS ditempatkan dalam jabatan dan pangkat tertentu. Hal tersebut juga berlaku pada instansi BKD Provinsi Jawa Tengah.

Tabel 2.

Jumlah Pegawai BKD Provinsi Jawa Tengah

\begin{tabular}{lll}
\hline No & Jabatan di BKD & Jumlah Pegawai \\
\hline 1 & Pejabat Pimpinan Tinggi Pratama & 1 orang \\
\hline 2 & Pejabat Administrator & 7 orang \\
\hline 3 & Pejabat Pengawas & 16 orang \\
\hline 4 & Pejabat Fungsional & 27 orang \\
\hline 5 & Pejabat Pelaksana & 111 orang \\
\hline & Total & 161 orang \\
\hline & Sumber $:$ http://simpeg.bkd.jatengprov.go.id,
\end{tabular}

Berdasarkan tabel tersebut dapat terlihat bahwa pada tahun 2019 Jumlah pegawai seluruh BKD Provinsi Jawa tengah sebanyak 161 orang yang menduduki jabatan terdiri 1 orang pejabat tinggi pratama (eselon 2) yaitu Kepala BKD, 6 orang pejabat administrator (eselon 3), 16 pejabat pengawas (eselon 4), 27 Pejabat Fungsional serta 111 Pejabat pelaksana. (Sumber: Data Kepegawaian BKD Provinsi Jawa Tengah, 2019).

Tahapan dalam Pengisian dan penempatan Jabatan Pelaksana di BKD Provinsi Jawa Tengah mengacu kepada UU No. 5 Tahun 2014 tentang Aparatur Sipil Negara dan PP No. 11 Tahun 2017 tentang manajemen Pegawai Negeri Sipil dilakukan dengan cara merit system yaitu dimulai dengan penyusunan formasi dan pengadaan pegawai, kemudian penentuan pangkat dan penempatan jabatan yang mempertimbangkan kualifikasi dan kompetensi baik kompetensi teknis, manajerial dan kompetensi sosio kultural.

Analisis yang dilakukan adalah mengkaji penerapan prinsip-prinsip merit system dalam pelaksanaan pengisian dan penempatan

\section{Proses dan Pelaksanaan Penempatan Pegawai dalam Konteks Sistem Merit}

Badan Kepegawaian Daerah Provinsi Jawa Tengah merupakan leading sector yang bertugas membantu Gubernur melaksanakan manajemen kepegawaian di Provinsi Jawa Tengah. Hal tersebut sesuai ketentuan Peraturan Pemerintah Nomor 159 Tahun 2000 dan Peraturan Gubernur Jawa Tengah No 83 Tahun 2016 tentang Organisasi dan Tata Kerja Badan Kepegawaian Daerah Provinsi Jawa Tengah. Berikut ini jumlah pegawai di BKD Provinsi Jawa Tengah pada tahun 2019 sebagai berikut: 
dan kompetensi tugas diukur pada waktu seleksi. Penempatan jabatan pelaksana yang berasal dari pegawai lama dengan cara ditempatkan bahwa setiap jabatan pelaksana wajib mendaftar karena berkaitan dengan penataan pegawai.

Realistic standards, Absence of discrimination dan Ranking on the basis of ability. Artinya adanya standar kualifikasi harus secara rasional berkaitan dengan pekerjaan yang akan diisi, dan harus berlaku secara imparsial atau adil yang berkaitan dengan kemampuan dan kesesuaian dalam jabatan serta esensi kompetensi mengindikasikan peringkat calon/kandidat atas dasar evaluasi relatif akan kecakapan dan kesesuaian mereka, dan proses seleksi yang dapat berimplikasi terhadap peringkat dimaksud.
Adapun penempatan yang berasal dari pengadaan pegawai di Pemerintah Provinsi Jawa Tengah dimulai pada tahun 2014 dan tahun 2018 dengan menggunakan Computer Assisted Test (CAT) yang merupakan tes dalam seleksi CPNS berbasis komputer, dimana nilai dapat dimonitor langsung oleh masyarakat umum saat peserta mengerjakan soal atau tes selesai. Hal tersebut sesuai dengan prinsip merit system yaitu penilaian berdasarkan kompetensi, adil, akuntabel dan transparan. Dapat ditegaskan juga bahwa seleksi atau pengadaan pegawai PNS dengan menggunakan standar kompetensi dasar dan kompetensi bidang. Penempatan CPNS seteleh lulus dan menjadi PNS dapat dilihat pada penempatan jabatan pelaksana di BKD Provinsi Jawa Tengah tabel 3:

Tabel 3.

Penempatan CPNS pada Jabatan Pelaksana di Pegawai BKD Provinsi Jawa Tengah

\begin{tabular}{|c|c|c|c|c|c|}
\hline NO & Formasi CPNS & $\begin{array}{l}\text { Kualifikasi } \\
\text { Pendidikan } \\
\text { untuk } \\
\text { menduduki } \\
\text { Jabatan }\end{array}$ & Uraian Tugas & $\begin{array}{l}\text { Penempatan } \\
\text { Jabatan di } \\
\text { CPNS }\end{array}$ & $\begin{array}{l}\text { Penempatan } \\
\text { Jabatan PNS }\end{array}$ \\
\hline $\mathbf{A}$ & $\begin{array}{l}\text { Formasi CPNS } \\
\text { tahun } 2014\end{array}$ & & & & \\
\hline 1. & $\begin{array}{l}\text { Pranata Laporan } \\
\text { Keuangan }\end{array}$ & S1 Akuntansi & $\begin{array}{l}\text { Melakukan kegiatan } \\
\text { penelaahan dan penataan } \\
\text { laporan keuangan sesuai } \\
\text { dengan prosedur yang } \\
\text { berlaku. }\end{array}$ & $\begin{array}{l}\text { Calon Pranata } \\
\text { Laporan } \\
\text { Keuangan BKD } \\
\text { Jateng }\end{array}$ & $\begin{array}{l}\text { Pranata } \\
\text { Laporan } \\
\text { Keuangan } \\
\text { BKD Jateng }\end{array}$ \\
\hline B & $\begin{array}{l}\text { Formasi CPNS } \\
\text { Tahun } 2018\end{array}$ & & & & \\
\hline 1. & $\begin{array}{l}\text { Penata Laporan } \\
\text { Keuangan }\end{array}$ & S1 Akuntansi & \begin{tabular}{lrr} 
Melakukan & \multicolumn{2}{r}{ kegiatan } \\
penataan bahan & dan \\
pemeriksaan & di bidang \\
laporan & & \\
keuangan & &
\end{tabular} & $\begin{array}{l}\text { Calon Penata } \\
\text { Laporan } \\
\text { Keuangan } \\
\text { Jateng }\end{array}$ & $\begin{array}{l}\text { Pranata } \\
\text { Laporan } \\
\text { Keuangan } \\
\text { BKD Jateng }\end{array}$ \\
\hline
\end{tabular}

Sumber: Data Kepegawaian BKD Provinsi Jawa Tengah, 2019

Sedangkan PNS yang perekruitannya dengan sistem lama penempatan jabatan masih ada yang belum sesuai dengan formasi pada saat formasi CPNS. Salah seorang narasumber BKD mengatakan bahwa :

"Kalau Seleksi CPNS sekarang sudah sesuai, jika yang sebelumnya masih belum sesuai misal perekrutan CPNS Pemprov Jateng ada jabatan pada lowongan formasi adalah sanitarian tapi setelah diangkat PNS dan penempatan jabatan menjadi jurnalis. Harus dipindahkan karena harus pindah beliau merupakan fungsional tidak bsa naik pangkat. Kecuali harus dapat rekomendasi dari kemenpan. (Dalam Workshop 11/5/2020)

Penataan dan penempatan keseluruhan pegawai khususnya jabatan pelaksana BKD Provinsi Jawa Tengah pada tahun 2018 dan dilanjutkan tahun 2019 sudah memulai dengan melaksanakan desk verifikasi penempatan PNS dengan melihat latarbelakang formasi, latar belakang pendidikan (syarat jabatan) kompetensi teknis (kompetensi berkaitan dengan tingkat 
spesialisasi pendidikan, pangkat, pelatihan teknis, dan pengalaman kerja/jabatan) yang diusulkan oleh Satuan Kerja Perangkat Daerah. BKD Provinsi Jawa Tengah berpedoman Peraturan Menteri PAN dan RB Nomor 41 Tahun 2018 tentang Nomenklatur Jabatan Pelaksana Bagi Pegawai Negeri Sipil Di Lingkungan Instansi Pemerintah. Salah seorang narasumber dari KemenPAN RB mengatakan bahwa :

Dalam mekanisme penempatan jabatan pelaksana sesuai dengan regulasi minimal sesuai dengan kualifikasi pendidikan formal dan/atau profesi yang dipersyaratkan dalam jabatan, serta kompetensi kebutuhan organisasi (Wawancara/17/9/2019)

Sementara itu dalam pelaksanaan verifikasi penempatan di BKD Provinsi Jawa Tengah masih ada 9\% pangkat dan kualifikasi persyaratan pendidikan masih ada yang belum sesuai

dipersyaratkan.(http://simpeg.bkd.jatengprov. go.id/, februari 2020 yang diolah). PNS yang belum sesuai penempatan merupakan PNS dengan menggunakan system perekrutan lama. Seperti kasus ada seorang dengan kualifikasi lulusan SLTP dan pangkat II/b di tempatkan pada Jabatan Pengadministrasi Umum, seharusnya jabatan tersebut dapat ditempati dengan kualifikasi persyaratan lulusan SMA dan pangkat minimal II/c. Kondisi ini berdampak terhadap ditempatkannya seseorang pada jabatan yang tidak sesuai dengan kompetensi dan keahliannya.

Praktik penilaian kompetensi di BKD Provinsi Jawa Tengah yang diatur berdasarkan Peraturan Menteri PAN dan RB nomor 38 Tahun 2017 Tentang Standar Kompetensi Jabatan Aparatur Sipil Negara dan Peraturan Kepala BKN Nomor 7 Tahun 2013 Tentang Pedoman Penyusunan Standar Kompetensi Manajerial Pegawai Negeri Sipil. Adapun penilaian kompetensi dan kinerja dilakukan oleh masing-masing atasan langsung kompetensi atau kemampuannya sehari-hari dalam bekerja dan melalui Sasaran Kerja Pegawai (SKP) bulanan, kedisiplinan dan kehadiran dalam finger print. Salah seorang narasumber BKD mengatakan bahwa :

Untuk penilian kompetensi di subbidang saya baik, saya melihat berdasarkan kualifikasi pendidikan dan pengalaman dari jabatan pelaksana atau staf, yang paling penting saya ukur adalah output/hasil pekerjaan masing- masing jabatan pelaksana serta perilakunya. (Wawancara, 13/5/2020)

SKP berisi tentang hasil pekerjaan dan perilaku seorang jabatan pelaksana. Penilaian SKP, finger print kehadiran dan tidak pernah dijatuhi hukuman disiplin berdampak pada tambahan penghasilan pegawai (TPP). Jika tidak memenuhi penilaian SKP nilai baik dan kurang jam kerja maka TPP akan dipotong. Dikarenakan berpengaruh pada TPP, kondisi penilaian SKP dari pimpinan juga dapat subjektifitas. Jika kehadiran fingerprint dan hukuman displin pasti objektif karena menggunakan sistem. Selain itu, dalam penilaian kinerja belum adanya pemeringkatan staf atau jabatan pelaksana.

Knowledge of results, Publik harus dapat mengetahui bagaimana proses berjalan, jika prosesnya tidak berjalan dengan semestinya, yang bersangkutan harus diberi kesempatan untuk melakukan tinjauan administratif. Dalam pelaksanaannya di BKD Provinsi Jawa Tengah bahwa pengisian dan penempatan jabatan pelaksana baik yang berasal dari CPNS maupun yang sudah berlangsung atau berjalan merupakan kewenangan prioritas dari pimpinan instansi yang diukur berdasarkan kualifikasi dan kompetensi, pelaksana hanya mempunyai kewenangan meninjau administratif jika terjadi kesalahan data kepegawaian

\section{Kriteria-Kriteria Penempatan Jabatan Pelaksana}

Kriteria-kriteria penempatan pegawai menurut Siagian (2013) Proses pengisian dan penempatan Jabatan Pelaksana di BKD Pemerintah Provinsi Jawa Tengah termasuk jabatan yang kosong dilakukan juga melalui 3 mekanisme yaitu promosi, rotasi/mutasi dan demosi.

Promosi di sini adalah promosi pegawai yang didasarkan oleh seseorang pegawai atas prestasi kerja, pengalaman dan tanggungjawab lebih besar, tingkatannya dalam jabatan yang lebih tinggi dan berdampak pada penghasila lebih besar pula bagi pegawai atau jenjang karir yang lebih tinggi.

Promosi jabatan pegawai dilakukan untuk mengisi jabatan administrasi baik jabatan pengawas maupun jabatan administrator melalui jalur penelusuran Kader (talent scouting) dalam setahun sekali sehingga akan mencetak kader yang potensial (talent 
pool). Jenjang karir jabatan pelaksana dapat menduduki jabatan pengawas (eselon IV) dengan mengikuti talent scouting dan harus memenuhi persyaratan yang ditetapkan sesuai Peraturan Gubernur Nomor 38 Tahun 2017 tentang Penelusuran Kader Potensial (Talent Scouting). Untuk kewenangan atasan langsung hanya bersifat memotivasi jabatan pelaksana untuk mengikuti promosi.

Mutasi atau transfer dapat mengambil salah satu dari dua bentuk yaitu pertama, penempatan seorang pada tugas baru dengan tanggung jawab hirarki jabatan dan penghasilan yang relatif sama dengan status dahulu. Kedua, Alih tugas penempatan pegawai yang tidak mengalami perubahan.

Adapun penempatan jabatan pelaksana di BKD Provinsi Jawa Tengah yang sudah ditempatkan, kemudian setelah diteliti kembali tidak sesuai dengan kualifikasi dan kompetensi, maka PNS tersebut dapat dimutasi ke bidang lain yang mendukung kualifikasi dan kompetensinya dan dapat menjalankan tugas yang optimal. Dalam mutasi pegawai tersebut dibuatkan Surat Keputusan dari Kepala BKD Provinsi Jawa Tengah seperti Contoh : Seorang Jabatan Pelaksana dengan kualifikasi Sarjana Komputer dan keahlian pada bidang IT ditempatkan pada Bidang yang tugas pokok dan fungsi bidang tidak memerlukan seorang sarjana komputer (berdasarkan data di peta jabatan), dengan dasar kualifikasi dan kompetensinya, maka seorang jabatan pelaksana PNS tersebut di pindah bidang yang menunjang kinerja individu dan organisasi.

Strategi pengisian jabatan pelaksana yang kosong, selain melakukan pengadaan pegawai atau CPNS yang belum tentu satu tahun sekali, BKD Pemerintah Provinsi Jawa Tengah melaksanakan kegiatan tes mutasi PNS ke lingkungan Provinsi Jawa Tengah meliputi, mutasi yang berasal dari Pemerintah Pusat atau Provinsi lain, Kabupaten/Kota dari Provinsi di wilayah Jawa Tengah maupun Kabupaten/Kota luar Provinsi Jawa Tengah yang sesuai dengan kualifikasi dan kompetensinya dengan tes mutasi sistem CAT (Computer Assisted Tes). Salah satu pengisian pejabat pelaksana yang kosong di BKD Provinsi Jateng berasal dari kegiatan tes mutasi tersebut.

Demosi merupakan tindakan seseorang, karena berbagai pertimbangan mengalami penurunan pangkat atau jabatan dan penghasilan serta tanggungjawab yang semakin kecil dan tidak ada seorang pegawai pun yang senang mengalami demosi. Jabatan Pelaksana di lingkungan BKD Provinsi Jawa Tengah selama ini belum mengalami demosi. Demosi juga dapat dilakukan apabila seorang PNS menduduki jabatan mengundurkan diri, tidak mampu melaksanakan tugas dan jabatan dan pegawai yang terkena hukuman disiplin sesuai Peraturan Pemerintah Nomor 53 tahun 2010 tentang Hukuman Disiplin Pegawai Negeri Sipil.

\section{Faktor-faktor yang Mempengaruhi Proses Pengisian dan Penempatan Pejabat Pelaksana}

Berdasarkan data yang dihimpun di lapangan baik dengan proses wawancara mendalam maupun studi pustaka maka faktor mempengaruhi proses pengisian dan penempatan pejabat pelaksana dalam pelaksanaan merit system di BKD Provinsi Jateng antara lain sebagai berikut :

Komitmen pimpinan dalam mengatur dan mengelola bawahannya berperan besar dalam penempatan PNS terutama juga jabatan pelaksana. Banyak pimpinan di Satuan Kerja Perangkat Daerah (SKPD) dalam menempatan pegawai masih memperhatikan like and dislike, tempat tinggal pegawai dan kenyamanan dalam komunikasi dengan bawahan. Pimpinan yang tegas dan sesuai dengan aturan normatif UU Nomor 5 Tahun 2014 tentang ASN, PP Nomor 11 tahun 2017 tentang manajemen PNS dan PermenPAN dan RB Nomor 40 tahun 2018 tentang Pedoman Sistem Merit Dalam Menajemen Aparatur Sistem Negara menempatkan pegawai sesuai kualifikasi dan kompetensi dan kinerja pegawai tersebut. Komitmen Kepala BKD Provinsi Jawa Tengah dalam menempatkan pegawainya berdasarkan kualifikasi dan kompetensinya dilakukan secara bertahap. Hal ini diungkapkan narasumber bahwa :

Pengembangan kompentesi sangat penting terutama dalam penempatan pegawai dan pengembangan karir selanjutnya (Workhsop/11/5/2020)

Komitmen pimpinan ini sangat dipengaruhi oleh kepentingan Kepala BKD Provinsi Jawa Tengah dalam rangka meningkatkan kinerja organisasi.

Sumber daya manusia sangat mempengaruhi kinerja organisasi. Sumber daya manusia yang dimaksud dapat dilihat dari 
segi kualitas dan kuantitasnya. Kualitas sumber daya manusia yang diharapkan mampu melakukan pekerjaan dengan baik, memahami tugas, tanggungjawabnya dan memiliki kompetensi yang handal dibidangnya. Pengadaan pegawai yang tidak diadakan setiap tahun dan banyaknya PNS yang pensiun setiap tahun telah menyebabkan banyak pejabat pelaksana kosong. Hal tersebut seperti diungkapkan salah satu narasumber di BKD Provinsi Jawa Tengah.

Regulasi yang berkaitan dengan penempatan PNS dalam jabatan berdasarkan prinsip merit system antara lain, UU Nomor 5 Tahun 2014 tentang ASN dan Peraturan Pemerintah nomor 11 Tahun 2017 tentang Manajemen PNS serta Peraturan MenPAN dan RB nomor 40 Tahun 2018 tentang Pedoman Sistem Merit Dalam Menajemen Aparatur Sistem Negara. Adapun dalam pelaksanaannya dilapangan di BKD Provinsi Jawa Tengah belum sepenuhnya $100 \%$ dapat dilaksanakan. BKD Provinsi Jawa Tengah sudah mulai menata secara bertahap penempatan pegawainya dimulai dari penyusunan formasi dan kebutuhan, pengadaan pegawai, sampai pada penentuan pangkat dan penempatan PNS dalam jabatan pelaksana. Regulasi penting dalam rangka memberikan panduan dalam penataan dan penempatan pegawai.

\section{SIMPULAN}

Terdapat perbedaan dalam pelaksanaan pengisian dan penempatan Jabatan Pelaksana di lokus penelitian yaitu pertama, pengisian dan penempatan jabatan pelaksana yang berasal dari pengadaan pegawai CPNS dengan sistem CAT (Computer Assisted Test) tahun 2014 dan tahun 2018 sudah sesuai dengan prinsip-prinsip merit system yang didasarkan pada kualifikasi, kompetensi, dan kinerja secara adil dan wajar. Hal tersebut ditegaskan juga bahwa sejak mulai pengadaan CPNS dengan menggunakan tes kompetensi dasar dan tes kompetensi bidang sampai pada lulus PNS, diangkat dan penempatan jabatan pelaksana di BKD Provinsi Jawa Tengah. Kedua, dalam pengisian dan penempatan Jabatan Pelaksana belum sepenuhnya menerapkan sistem merit system dikarenakan masih terdapat penempatan PNS yang belum sesuai dengan kebutuhan jabatan yaiutukualifikasi dan pangkat yang dipersyaratkan dalam menduduki jabatan tersebut (job spesification).
Selain itu, dalam mengisi dan menempatkan setiap jabatan pelaksana yang kosong masih terdapat subjektivitas pimpinan dalam menilai kompetensi dan kinerja yang berdasarkan Sasaran Kinerja Pegawai (SKP). Hal ini juga berlaku penilaian dari pimpinan berkenaan promosi, mutasi dan demosi penempatan pegawai.

Penilaian kinerja melalui Sasaran Kerja Pegawai (SKP) bulanan oleh atasan langsung, kedisiplinan dan kehadiran fingerprint yang berpengaruh pada Tambahan Penghasilan Pegawai (TPP). Pejabat pelaksana yang sudah ditempatkan tidak mengetahui bagaimana proses penempatan berjalan. Apabila prosesnya tidak berjalan dengan semestinya, yang bersangkutan diberi kesempatan untuk melakukan tinjauan administratif hanya bersifat jika terjadi kesalahan data kepegawaian.

Terdapat beberapa faktor yang mempengaruhi proses pengisian dan penempatan jabatan pelaksana pada lokus penelitian, antara lain: komitmen pimpinan, sumber daya manusia dan regulasi.

\section{DAFTAR PUSTAKA}

Administrasi, J. R. (2020). Analisis Proses Pengisian Jabatan Administrasi Berbasis Merit System di Kementerian Energi dan Sumber Daya Mineral. 7(1), 17-28.

Ali, D. M. (n.d.). The Transformation of Merit System in Indonesian Civil Servant Promotion System. 5(04).

Hardiyanto, (2011), Proses Pengangkatan Pegawai Negeri Sipil Dalam Jabatan Struktural (Studi pada Pemerintah Kabupaten Labuhanbatu), Jurnal Administrasi Publik : Public Administration Journal : Public Admnistration Journal, 1 (1): 65-81

Miles,M.B, Huberman,A.M, dan Saldana,J. 2014. Qualitative Data Analysis, A Methods Sourcebook, Edition 3. USA: Sage Publications. Terjemahan Tjetjep Rohindi Rohidi, UI-Press.

Pulungan, I., (2011), Strategi Badan Kepegawaian Daerah Kota Binjai Dalam Meningkatkan Kinerja Pegawai Negeri Sipil, Jurnal Administrasi Publik : Public Administration Journal : Public Admnistration Journal, 1 (1): 82-101

Putri, A. D., AM, E., \& Candradewini, C. (2017). Penempatan Pegawai Di Badan Kepegawaian Daerah Kota Bandar Lampung. JANE - Jurnal Administrasi Negara, 2(1), 1-9. https://doi.org/10.24198/jane.v2i1.13677 
Ahmad Faiz, Retno Sunu Astuti \& Teuku Afrizal, Sistem Merit pada Sektor Pemerintahan : Proses

Siregar, S., Irwan, N., Indra, M., (2017). Peranan Badan Kepegawaian Daerah Dalam Rekruitmen Pegawai Negeri Sipil Di Kabupaten Padang Lawas. PERSPEKTIF, 6 (1): 18-24

Series, I. O. P. C., \& Science, M. (2017). Merit System in The Placement of Civil Servants and its Effect toward Performance of Sub-district Office in Labuhanbatu Region Nort Sumatera Merit System in The Placement of Civil Servants and its Effect toward Performance of Sub-district Office in Labuha. https://doi.org/10.1088/1742$6596 / 755 / 1 / 011001$

Setyowati, E. (2016). Merit System in Recruitment and Selection Process of Civil Servant Candidate in Malang Indonesia (Implementation of Recruitment and Selection of Civil Servant Candidate in 2010). Journal of Administrative Sciences and Policy Studies, $\quad 4(1)$, 83-95. https://doi.org/10.15640/jasps.v4n1a5

Siagian, Sondang P. (2013). Manajemen Sumber Daya Manusia. Jakarta: Bumi Aksara

Stahl, G. O. (1962). Public Personnel Administration. London: Harper \& Row

Teguh Sulistiyani, Ambar dan Rosidah.(2003). MSDM konsep, teori dan pengembangan dalam konteks organisasi publik. Yogyakarta:Graha Ilmu

Utha, A., \& Dinamita, K. (2017). Analysis of Factors Affecting the Placement of the Civil Servants As Structural Officials on Local Government. International Journal of Information Research and Review, 04(01), 3589-3592.

Wijaya, A. F., Kartika, R., Zauhar, S., \& Mardiyono, M. (2019). Perspective merit system on placement regulation of high level official civil servants (a Case Study of placement civil servants in Local Government on Palembang). HOLISTICA - Journal of Business and Public Administration, 10(2), 187-206. https://doi.org/10.2478/hjbpa-2019-0025.

Undang-Undang Nomor 5 Tahun 2014 tentang Aparatur Sipil Negara (ASN).

Undang-Undang Nomor 43 Tahun 1999 tentang Perubahan atas Undang-Undang No. 8 Tahun 1974 tentang Pokok-pokok Kepegawaian

Peraturan Pemerintah Nomor 11 Tahun 2017 tentang Manajemen PNS

UU 5 Tahun 2014, ASN terdiri dari PNS dan PPPK

PP 11Tahun 2017, manajemen PPPK diatur tersendiri dalam PP 49 Tahun 2018. 